\title{
RECENZJE
}

\section{Tadeusz J. Zieliński, Państwowy Kościół Anglii. Studium prawa wyznaniowego, Wydawnictwo Naukowe ChAT, Warszawa 2016, ss. 457}

Prawo wyznaniowe stanowi niewątpliwie bardzo specyficzny obszar systemu normatywnego. Z uwagi na swój charakter, który prima facie zdaje się je sytuować w drugim planie dyscyplin prawnych, w rzeczywistości dotyka bezpośrednio newralgicznych obszarów prawa konstytucyjnego, stanowiącego centrum współczesnych, państwowych systemów prawnych. Co więcej, problematyka znajdująca się w obszarze prawa wyznaniowego zawsze budzi ogromne emocje społeczne, co nadaje tej dyscyplinie tym większej doniosłości.

$\mathrm{Z}$ tych też powodów relacje między państwem a wspólnotą religijną w warunkach ścisłego instytucjonalnego powiązania winny zainteresować wielu czytelników. Niedawno też polska doktryna prawa wyznaniowego wzbogaciła się o bardzo ważną w tej mierze pozycję, przybliżającą w sposób systematyczny sytuację Kościoła Anglii. Monografia Tadeusza J. Zielińskiego Państwowy Kościół Anglii. Studium prawa wyznaniowego ma bardzo klarowną strukturę. Podzielona jest na dwie niemal równe części, z których każda liczy 10 rozdziałów, mających wstęp i zakończenie. Całości dopełnia wykaz aktów prawnych usystematyzowany ze względu na rodzaj tekstów normatywnych, wreszcie wykaz literatury i anglojęzyczne streszczenie.

Pierwsza część zawiera opis historycznego procesu kształtowania się instytucji Kościoła Anglii, poprzedzony syntetycznym przedstawieniem rozwoju chrześcijaństwa przed reformacją na Wyspach Brytyjskich. Druga część stanowi natomiast systematyczny opis współczesnego ustroju państwowego Kościoła Anglii i zespolenia jego struktur 
z instytucjami państwowymi na poszczególnych szczeblach jego organizacji. Autor omawia tu samą podmiotowość Kościoła Anglii, jego strukturę instytucjonalną, wreszcie aspekty funkcjonalne i majątkowe. Jak podkreśla już we wstępie, każdy z rozdziałów kończy się podsumowaniem, przy czym niektóre mają charakter streszczeń, inne bardziej syntetycznego wywodu, połączonego niekiedy z uogólniającą refleksją wykraczającą poza formułę technicznego streszczenia.

Praca stoi na wysokim poziomie. Autor radzi sobie znakomicie z nader obfitym materiałem faktograficznym. Jest rzeczowy w swych wywodach i wyczerpujący w podawaniu faktografii. Niekiedy ta ostatnia okoliczność sprawia, że na stronach rozprawy czytamy niezwykle rozległe, techniczne wyliczenia ustaw (s. 56) lub innych danych (s. 197, 399, 405). Warto się zastanowić, czy nie dałoby się znaleźć redakcyjnej formuły pozwalającej na przeniesienie tych treści z zasadniczego tekstu do przypisów lub aneksów. Pozwoliłoby to uczynić właściwy wywód rozprawy bardziej zwartym. Uwaga ta nie wpływa jednak na ogólną ocenę rozprawy, która prezentuje bardzo wysoki poziom merytoryczny.

Zastosowany w książce podział na część historyczną i systematyczną, choć pod wieloma względami uzasadniony, pociąga za sobą - jak każdy wybór kompozycyjny - również pewne koszty. Utrudnia bowiem zachowanie ciągłości w sposobie prezentowania angielskiego prawa wyznaniowego. Być może podział materii rozprawy na zagadnienia merytoryczne, które prezentowane byłyby jako historyczne continuum, mógłby pomóc w uchwyceniu pewnych procesów, które obecnie są słabo dostrzegalne. Tymczasem akurat na gruncie angielskiej kultury prawnej owa historyczna linearność jest niezwykle istotna. W konsekwencji, choć autor stara się wciąż nawiązywać w części systematycznej do swoich ustaleń z części historycznej, podkreślając związek między nimi zachodzący, w wywodzie powstają niekiedy pewne „dziury” i nieciągłości.

Przykładowo, można w tym miejscu wskazać na problematykę działalności dobroczynnej (autor nader zasadnie stosuje polską terminologię prawną, pisząc o „działalności pożytku publicznego”). Z jednej strony, odnotowano w monografii historyczne początki tego specyficznego obszaru regulacji prawnej w postaci prawodawstwa Elżbietańskiego (s. 69), później zaś szczegółowo opisywane są współczesne regulacje 
Charities Act 2011 (s. 375 n.) i osobno zasygnalizowano wątek fiskalny (s. 390). Brakuje jednak syntetycznego, kilkuzdaniowego zarysu ogólnego kontekstu instytucjonalnego, który pozwalałby lepiej wyjaśnić kształtowanie się angielskiego charity law w kontekście zasad zakazujących dokonywania podstawień powierniczych na czas nieograniczony (rule against perpetuities) oraz utworzenia specjalnego państwowego nadzoru (Komisarzy Królewskich, później Attorney-General, a począwszy od Charities Act 1964 (sekcja 4), Charity Commission) nad administrowaniem tymi majątkami. Problematyka ta wiąże się zresztą już ściśle $\mathrm{z}$ tematyką monografii, dotyka bowiem między innymi przejęcia majątków kościelnych w czasie reformacji. Nie bez znaczenia byłoby bliższe pokazanie (wykraczające poza konstatację ze s. 377), jak doszło do szczególnego sposobu ukształtowania zakresu znaczeniowego kategorii charitable purpose, której obecny kształt odnajdujemy w wyliczeniu na s. 375-376 i którego główna doniosłość wiąże się od końca XVIII w. $\mathrm{z}$ przywilejami podatkowymi. Znowu jest to $\mathrm{w}$ książce odnotowane (s. 390), jednak raczej jako pewna normatywna koincydencja niż jako istotny aspekt tej samej problematyki, stanowiący dodatkowo od schyłku XIX w. dominantę rozwoju charity law.

Autor wiele uwagi poświęca angielskiej terminologii, nie wahając się obszernie tłumaczyć wyborów, jakich dokonywał przy tłumaczeniu. Czyni to, począwszy od samego tytułu, jednak w całym tekście rozprawy, $\mathrm{w}$ wielu miejscach zawiera liczne wyjaśnienia wyborów terminologicznych, których dokonuje, zachowując w tej wierze niesłabnącą ,czujność”. Praca jest pod tym względem nader staranna, zaś dokonywane wybory niemal zawsze budzą uznanie. Nie sposób tu mówić o przypadkowości lub bezrefleksyjnym spolszczaniu angielskich terminów, nieliczącym się z ich semantyczną zawartością.

Nie znaczy to jednak, by nie zdarzały się niekiedy potknięcia. Ma to miejsce na s. 180, gdzie relacjonując podstawowe rozwiązania prawne Human Rights Act 1998, autor posługuje się mało prawniczym, wręcz można byłoby rzec - potocznym, terminem „bezprawie” dla oddania angielskiego "unlawful”. Zdecydowanie trafniej byłoby tłumaczyć to pojęcie, odwołując się do kategorii „bezprawności”, nie zaś „bezprawia”. Być może zresztą zawiniła tu (skądinąd niezwykle staranna - jedyną 
literówkę zauważyłem na s. 47) redakcja tekstu książki, bowiem w korespondującym co do meritum artykule autora mowa jest już o działaniu bezprawnym ${ }^{1}$. Jednocześnie jednak brak jest w tekście wskazania, do jakiej jednostki redakcyjnej omawianej ustawy autor się odnosi. Zapewne chodzi o dyspozycję sekcji 6 (1) Human Rights Act 1998, przy czym z nieznanych powodów - nie uwzględniono sekcji 6 (2), której treść jest niezbędna do właściwego zrekonstruowania całej normy. $\mathrm{O}$ ile bowiem w książce mówi się o skutkach niezgodności z Europejską Konwencją Praw Człowieka przy użyciu kwantyfikatora ogólnego („Naruszenie norm konwencyjnych uznano za bezprawie”), o tyle uwzględnienie drugiego ustępu (subsection) nakazuje posługiwanie się kwantyfikatorem szczegółowym. Normatywną zawartość tych przepisów należałoby ująć zatem w sposób bardziej zniuansowany: niezgodne z EKPC działania organów publicznych są bezprawne, o ile obowiązujące unormowania ustawowe wyraźnie nie wymagają od organów takiego działania. Sytuacja zaś niemożliwego do uniknięcia konfliktu między prawem angielskim i unormowaniami EKPC otwiera drogę do zadeklarowania niezgodności w tym względzie, o czym w dalszym ciągu autor pisze. Zresztą widać, że pisząc ten fragment książki, T.J. Zieliński raczej nie korzystał bezpośrednio z tekstu samej ustawy, lecz bazował na swoim odrębnym tekście poświęconym kontroli unormowań brytyjskich wspólnot religijnych w trybie przewidzianym przez HRA 1998, przy czym również tam autor nie uwzględnił treści sekcji 6 (2).

Wspomniane uwagi krytyczne nie zmieniają bardzo pozytywnej oceny merytorycznego kształtu wywodów, opisujących sytuację prawną Kościoła Anglii. Nie dotyczą one zagadnień, które mogłyby podawać w wątpliwość jakość tego opracowania.

Da się jednak niekiedy odczuć niedosyt pogłębienia syntetyzujących partii książki. Ten subiektywny niedosyt istnieje, chociaż autor nader rzetelnie stara się przedstawiać poszczególne regulacje prawne dotyczące działalności Kościoła Anglii. Mimo to wyraźnie brakuje

1 T.J. ZielińsKi, Kontrola norm brytyjskich wspólnot religijnych $w$ trybie ustawy o prawach człowieka, [w:] Prawo państwowe a prawo wewnętrzne związków wyznaniowych, red. K. Krasowski, M. Materniak-Pawlowska, M. Stanulewicz, Poznań 2010, s. 241. 
metaperspektywy, która pozwalałaby na powiązanie wielu opisywanych faktów i ukazanie ich w pełniejszym świetle. Z pewnością uwagi te wynikają zwyczajnie $\mathrm{z}$ różnicy perspektyw i wrażliwości, jednak zawarta w książce faktograficzna prezentacja reformacyjnego ustawodawstwa kodyfikującego prawdy wiary jako akty prawa państwowego wręcz prosi się o uwzględnienie intelektualnego kontekstu, który odnaleźć można chociażby w wywodach Tomasza Hobbesa dokonującego głębokiego utożsamienia władzy świeckiej i religijnej, posługując się również argumentami biblijnymi ${ }^{2}$. Trudno przy tym przejść obojętnie nad stwierdzeniami tego filozofa, mówiącymi, że „w królestwie Bożym polityka i prawa państwowe są częścią religii; a wobec tego różnica między władzą świecką i duchową tutaj nie istnieje"3. Dodatkowego, frapującego kontekstu dostarcza zbieżność czasowa między wydaniem Lewiatana (1651) i Instrument of Government (1653).

Wskazując na brak tej kulturowej metaperspektywy, nie chodzi bynajmniej o znaczną rozbudowę treści książki, ale o uwzględnienie szerszego kontekstu intelektualnego przy relacjonowaniu faktów. Pojawia się on nieco później na kanwie Toleration Act 1689, powiązanego zasadnie z poglądami Johna Locke’a. Jednak również tu można odczuć niedosyt poszukiwań metalogiki opisywanych wydarzeń oraz zajmowanych stanowisk. Wydaje się tymczasem, że opis instytucji systematycznie dyskryminujących 'innowierców’, zwłaszcza w kontekście stałych oraz zmiennych elementów tej dyskryminowanej grupy, pozwala na dokonanie wielu ciekawych spostrzeżeń natury ogólnej.

Nader wyraźnie widać wówczas, w jaki sposób państwo traktuje religię jako instrumentum regni i w zależności od tego, która grupa wyznaniowa jest uznawana za zagrożenie dla racji stanu, tej grupie poświęca się najwięcej uwagi w polityce religijnej dyskryminacji. Zachodzenie tych prawidłowości potwierdzają również przemiany, jakie zachodziły $\mathrm{w}$ tej mierze wraz $\mathrm{z}$ narastaniem procesów sekularyzacji, kiedy to rola religii jako regulatora życia społecznego malała. Słabła wówczas konsekwentnie determinacja do dyskryminacji religijnej nieanglikanów,

T. Hobbes, Lewiatan, tłum. Cz. Znamierowski, Warszawa 1954, s. 419. Ibidem, s 102. 
a granice skłonności do tolerancji wyznaczały te aspekty życia społecznego, w których religia wciąż odgrywa istotną rolę. Dlatego można wątpić, czy stopniowe odchodzenie od regulacji dyskryminujących nieanglikanów przypisać należy bardziej staraniom innowierców, którzy mieli sobie wywalczyć na przestrzeni wieków szerokie swobody (jak sugeruje autor), czy raczej brakiem politycznego interesu państwa w dalszym upośledzaniu innych wyznań w określonych obszarach.

Zresztą również w relacjach Państwo - Kościół państwowy widać pewne charakterystyczne przemiany związane z sekularyzacją życia społecznego. $Z$ jednej strony, prawo państwowe przejmowało kompetencje regulacyjne $\mathrm{w}$ sferach uznanych za społecznie istotne (prawo małżeńskie), z drugiej zaś strony, wraz z powolnym spadkiem znaczenia religii dla życia społecznego, państwo dokonuje dewolucji swoich suwerennych uprawnień do określania ustroju Kościoła Anglii na rzecz ciał wewnątrzkościelnych, jak to ma miejsce w kontekście utworzenia National Assembly of the Church of England przez Enabling Act, a następnie Synodical Government Measure 1969 i National Institutions Measure 1998. Widać wyraźnie, że zasadnicze struktury władzy z czasem są coraz słabiej zainteresowane bezpośrednim zaangażowaniem w sprawy Kościoła Anglii i całkowicie wystarczają im instrumenty nadzorcze nad działaniami struktur kościelnych, którym zapewnia się jednocześnie większą autonomię. Chociaż więc w książce odnotowuje się te wszystkie przemiany, wskazując również na pewne „pragmatyczne” lub „prozaiczne” motywy ich wprowadzania, to autor nie kusi się już o spojrzenie na całą problematykę z bardziej ogólnej perspektywy. Poprzestaje na uzasadnieniu poszczególnych „kroków” i nie próbuje ustalić ogólniejszego „azymutu” przemian, które są opisywane.

Niezwykle ciekawe refleksje nasuwają się również na kanwie współczesnych interakcji między statusem kościoła państwowego i angielskim prawem antydyskryminacyjnym. Problematykę tę autor opisuje dość dokładnie, jednak znowu pojawia się pewien niedosyt metarefleksji. Powstaje bowiem pytanie o wzajemną relację między wpływem, jaki chrześcijańska tożsamość anglikanizmu ma na kształt współczesnego prawa, a wpływem, jaki zyskuje na nie ideologia równościowa. Czy nie jest tak, że szczególny status oficjalnego państwowego Kościoła Anglii 
nie pozwala mu już wpływać na tożsamość i treść prawa państwowego, ale wystarcza jeszcze, by zachować pewne enklawy wyłączone spod działania ogólnych zasad determinowanych przez zupełnie inne stanowiska kulturowe? W tym też kontekście, pointa rozprawy, w postaci stwierdzenia Królowej Elżbiety II o funkcji anglikanizmu jako gwaranta pluralizmu religijnego i światopoglądowego w przestrzeni publicznej Wielkiej Brytanii, stanowi niezwykle ciekawy przyczynek do refleksji nad współczesną kulturą.

Niezależnie więc od pewnego subiektywnego niedosytu w zakresie pogłębionych ujęć syntetycznych, nie ulega wątpliwości, że monografia Tadeusza J. Zielińskiego Państwowy Kościół Anglii. Studium prawa wyznaniowego stanowi cenną pozycję w dorobku polskiego prawa wyznaniowego.

Aleksander Stępkowski*

* Wydział Prawa i Administracji Uniwersytetu Warszawskiego. 